\title{
Applications and analysis of hydrolysates in animal cell culture
}

\author{
Yin Ying $\mathrm{Ho}^{\dagger}$, Hao Kim Lu+, Zhi Feng Sherman Lim, Hao Wei Lim, Ying Swan Ho and Say Kong Ng ${ }^{*}$ (i)
}

\begin{abstract}
Animal cells are used in the manufacturing of complex biotherapeutic products since the 1980s. From its initial uses in biological research to its current importance in the biopharmaceutical industry, many types of culture media were developed: from serum-based media to serum-free to protein-free chemically defined media. The cultivation of animal cells economically has become the ultimate goal in the field of biomanufacturing. Serum serves as a source of amino acids, lipids, proteins and most importantly growth factors and hormones, which are essential for many cell types. However, the use of serum is unfavorable due to its high price tag, increased lot-to-lot variations and potential risk of microbial contamination. Efforts are progressively being made to replace serum with recombinant proteins such as growth factors, cytokines and hormones, as well as supplementation with lipids, vitamins, trace elements and hydrolysates. While hydrolysates are more complex, they provide a diverse source of nutrients to animal cells, with potential beneficial effects beyond the nutritional value. In this review, we discuss the use of hydrolysates in animal cell culture and briefly cover the composition of hydrolysates, mode of action and potential contaminants with some perspectives on its potential role in animal cell culture media formulations in the future.
\end{abstract}

Keywords: Hydrolysates, Animal cells, Cell culture

\section{Introduction}

Biopharmaceutical products are playing an increasingly important role in the management and treatment of diseases ranging from infections to enzymatic deficiencies and cancers. According to a recent market report published by Mordor Intelligence, the biopharmaceutical market has reached approximately $\$ 325.17$ billion in 2020 with a compound annual growth rate (CAGR) of 7.32\% from 2021 to 2026, that is a revenue of $\$ 496.71$ billion in 2026 (Mordor Intelligence 2021). A prominent example of a biopharmaceutical product is monoclonal antibodies (mAbs), which are becoming the standard of care for indications in oncology and inflammation. Despite the Covid-19 pandemic, $\mathrm{mAb}$ therapeutic sales are expected to grow to $\$ 114.43$

\footnotetext{
*Correspondence: ng_say_kong@bti.a-star.edu.sg

†Yin Ying Ho and Hao Kim Lu contributed equally

Bioprocessing Technology Institute, Agency for Science,

Technology, and Research (A*STAR), 20 Biopolis Way, \#06-01 Centros,

Singapore 138668, Singapore
}

billion in 2021 and reach $\$ 179.56$ billion in 2025, a CAGR of $11.9 \%$ (The Business Research Company 2021). Currently, the majority of the biopharmaceutical products are made using animal cell systems because of their ability to produce correctly folded and fully glycosylated proteins that other simpler organisms cannot replicate ( $\mathrm{Li}$ et al. 2010). The ultimate goal of process development in animal cell culture is to increase product quality and yield while reducing cost. However, despite constant bioprocessing improvement in both upstream and downstream operations, high production cost remains the bottleneck that limits demand (Xu et al. 2020). The cell culture medium is an important component of raw materials that contributes significantly to the cost of production. Based on the type of supplements added, animal cell culture media can be broadly described as chemically defined medium, protein-free medium, animal component-free medium and serum-containing medium (Yao and Asayama 2017). Almost all cell lines were originally developed in media 
that contain animal serum and later adapted to serumfree media. Serum-supplemented medium is effective for a variety of cell types as it contains an abundance of known and unknown factors such as growth factors, hormones and lipid components that are necessary for the survival and proliferation of cells (O'Flaherty and Bergin 2020). However, the use of animal serum in media not only increases the risk of contamination with infectious agents, but also contributes significantly to the cost of production (O'Flaherty and Bergin 2020). Researchers are increasingly moving away from the use of animal serum and into animal-component-free media. The removal of serum not only improves production consistency, resulting in less batch-to-batch variability, but also reduces downstream processing time and cost. Many scientists have embarked on the journey in exploring alternatives to serum, to discover simple, low-cost and highly reproducible media for culturing animal cells. Current alternatives to serum include the use of a combination of recombinant proteins (e.g., insulin and other growth factors), hormones (e.g., hydrocortisone), lipids, and hydrolysates.

Hydrolysates are the products of plant (soy, pea, rice, rapeseed, etc.) or animal (chicken, pork, fish, etc.) proteins after hydrolysis by acid, alkali, enzymes and fermentation processes. When a predominantly protein starting material is used to produce the hydrolysate, the product may be described as a protein hydrolysate, for example, rice protein hydrolysate and rapeseed protein hydrolysate. Hydrolysates often contain a mixture of peptides, amino acids, minerals, carbohydrates, lipids and proteins that are similar to the raw input material. Since the late 1970s, chicken and fish-derived hydrolysates, have been used as serum replacements for animal cell culture (Mizrahi 1977). However, as animalderived hydrolysate would encounter the same issues as using animal serum, the use of plant-based hydrolysates such as those derived from soy, rice and cottonseed proteins have gained popularity. The relatively low cost of plant-based hydrolysates makes them attractive as serum replacement components for large-scale protein production. However, given hydrolysate products are not fully characterized, further understanding of their components and how these can influence cell growth and maintenance is key to their success as potential serum replacement components. In this review, we will describe the history of animal cell culture, including examples of animal cell cultures used for the production of biotherapeutics in the presence or absence of serum, the history of the use of hydrolysates in animal cell cultures for biotherapeutics and new modalities such as cultured meat production. The review will also describe the compositions of hydrolysate products, their modes of action and potential contaminants with some views on their future use in animal cell cultures.

\section{The advent of animal cell culture and its use in biotherapeutics production}

The ability to culture and study cells outside of the animal/host's body in the last 150 years has led to the development of modern science and medicine that we know today. The first attempt of cell culture dates back to the late nineteenth century when Wilhelm Roux demonstrated that it is possible to maintain living cells of the neural plate of the chick embryo in saline for a few days (Rodríguez-Hernandez et al. 2014). More successful attempts at tissue culture were achieved when a small amount of serum or lymph was added to the culture. In 1907, Ross Granville Harrison developed a reproducible technique of tissue culture by placing the neural tube frog embryo into a drop of fresh lymph and inverted the coverslip, generating the first hanging drop culture technique (Harrison et al. 1907). The first tissue culture of animal cells was described a few years later by Montrose Burrows and Alexis Carrel using culture media that contains animal plasma (Carrel and Burrows 1911a, b). They also demonstrated that these cell lines can be maintained in culture for several months and that the cells could grow extensively in media containing plasma of other mammals including rabbits, dogs, or humans (Carrel and Burrows 1911a, b). However, it was not until 1948 that the first cell line, L929, a mouse connective tissue fibroblast was established (Earle et al. 1943). In 1951, an aggressive adenocarcinoma of the cervix gave rise to HeLa cell (Gey 1952), one of the most commonly used human cell lines for medical research. The establishment of cell lines has not only contributed to our understanding of many diseases, but it has also become an invaluable tool for the production of biotherapeutics, ranging from recombinant protein biologics to virus production for gene therapy (Table 1).

In 1975, the first large-scale production of antibodies was described by Georges Köhler and Cesar Milstein (1975). They combined an antibody-producing B cell with a myeloma cell line; the resulting hybridoma acquired the ability to divide rapidly and at the same time produce the antibody. Since then, antibodies and other recombinant proteins have become the predominant products in the biopharmaceutical industry. Animal cells are the preferred choice for biotherapeutic manufacturing as these cell lines are capable of producing complex proteins with post-translational modifications similar to those produced in humans (Durocher and Butler 2009; Ghaderi et al. 2012; Sha et al. 2016). In addition, animal cells can secrete proteins efficiently and at high titers, 
Table 1 Establishment of important cell lines for research and biopharmaceutical manufacturing in order of year of origin

\begin{tabular}{|c|c|c|c|c|}
\hline Name & Species and tissue & Morphology & $\begin{array}{l}\text { Culture in serum-free } \\
\text { media }\end{array}$ & Year of origin \\
\hline L929 & Mouse connective tissue & Fibroblast & No & 1948; Earle et al. (1943) \\
\hline HeLa & Human cervix & Epithelial & Yes & 1951; Gey (1952) \\
\hline $\mathrm{CHO}$ & Chinese hamster ovary & Epithelial-like & Yes & 1957; Tjio and Puck (1958) \\
\hline $\begin{array}{l}\text { Baby hamster kid- } \\
\text { ney (BHK) cells }\end{array}$ & Hamster kidney cells & Fibroblast & Yes & 1961; Hernandez and Brown (2010) \\
\hline Vero & African green monkey kidney & Fibroblast & Yes & 1962; Yasumura and Kawakita (1963) \\
\hline 3Т3 & Mouse embryo & Fibroblast & No & 1962; Todaro and Green (1963) \\
\hline $\mathrm{U}-2 \mathrm{OS}$ & Human osteosarcoma & Epithelial & No & 1964; Ponten and Saksela (1967) \\
\hline MCF 7 & Human adenocarcinoma & Epithelial & No & 1970; Soule et al. (1973) \\
\hline HT1080 & Human fibrosarcoma & Epithelial & No & 1974; Rasheed et al. (1974) \\
\hline $\mathrm{Sp} 2 / 0$ & $\begin{array}{l}\text { Fused BALB/c mouse spleen cell and } \\
\text { mouse myeloma P3X63Ag8 }\end{array}$ & Lymphoblast & Yes & 1975; KÖHler and Milstein (1975) \\
\hline Caco-2 & Human colorectal adenocarcinoma & Epithelial & No & 1977; Fogh et al. (1977) \\
\hline Jurkat & Human T cell leukemia & Lymphoblast & No & 1977; Schneider, et al. (1977) \\
\hline HEK293 & Human embryonic kidney & Epithelial & Yes & 1977; Graham et al. (1977) \\
\hline THP-1 & Human monocytic leukemia & Monocytic & Yes & 1980; Tsuchiya et al. (1980) \\
\hline NSO & Murine myeloma & Lymphoblast & Yes & 1981; Galfrè and Milstein (1981) \\
\hline PER.C6 & Human embryonic retinal cells & Epithelial & Yes & 1999; Havenga et al. (2008) \\
\hline HKB-11 & human hybrid kidney/B cell & Epithelial & Yes & 2001; Cho et al. (2003) \\
\hline AGE1.CR & Duck embryo & Fibroblast & Yes & 2007; Jordan et al. (2009) \\
\hline $\begin{array}{l}\text { CEVEC's amniocyte } \\
\text { production (CAP) }\end{array}$ & Primary human amniocytes & Epithelial & Yes & 2011; Wölfel et al. (2011) \\
\hline
\end{tabular}

facilitating protein production and purification (Dumont et al. 2016).

In 1986, the first therapeutic protein, the human plasminogen activator, produced in the Chinese Hamster Ovary $(\mathrm{CHO})$ cell line was approved by the US Food and Drug Administration (FDA) (Wurm 2004). Since then, the $\mathrm{CHO}$ cell system has continued to be the leading cell line of choice for human therapeutic production, accounting for $\sim 70 \%$ of recombinant protein production in the 2000s (Jayapal et al. 2007). The popularity of CHO cells and $\mathrm{CHO}$ variants can be attributed to the following reasons. Firstly, $\mathrm{CHO}$ cells can grow in serum-free chemically defined media in suspension culture. The removal of serum reduces lot-to-lot variability and produces an improved safety profile for the therapeutic protein, in comparison to therapeutic protein produced in media containing animal-derived proteins. Secondly, since the first approved therapeutic protein was produced in $\mathrm{CHO}$ cells and with more than three decades of safety data, it may be easier to obtain regulatory and consumer acceptance. Thirdly, being a hamster-derived cell line, $\mathrm{CHO}$ cells are less susceptible to certain human viral infections, likely because some of the human viral entry genes are not expressed in these cells (Xu et al. 2011). Finally, a powerful system of gene amplification, such as dihydrofolate reductase (DHFR) or glutamine synthetase (GS) has previously been described in $\mathrm{CHO}$ cells. These gene amplification systems can improve recombinant protein yield and specific productivity, which was previously an issue in other animal cell lines (Kim et al. 2012; Dumont et al. 2016).

Despite the popularity of the $\mathrm{CHO}$ cell line in protein therapeutic production, it is unable to produce the full range of glycosylation found in humans (Patnaik and Stanley 2006), while it also produces rodent-specific glycan structures that may lead to increased immunogenicity in humans (Bosques et al. 2010; Ghaderi et al. 2012). This has led to the use of human-derived cell lines such as HEK293 (Human Embryonic Kidney cells) for therapeutic protein production. HEK293 can be easily grown in suspension serum-free culture; the cells also grow rapidly, possess superior transfection efficiency and express high levels of protein (Vink et al. 2014). Other variants of this cell line, such as HEK293-T, express an allele of the simian virus 40 large $\mathrm{T}$ antigen and are capable of expressing high titers of viral gene vectors (Yamaguchi et al. 2003). HEK293-T cells are often used for the production of retroviral vectors for cell and gene therapy (Ferreira et al. 2019).

While both CHO and HEK293 are capable of growing in serum-free media, we noted that both cell lines are immortalized and may have accumulated undefined 
mutations to survive without serum. Although HEK293 became an immortalized cell line after being transformed with sheared adenovirus-5 DNA (Kovesdi and Hedley 2010), CHO cells were immortalized spontaneously (Wurm and Wurm 2017). Some other cell lines have not been reported to be capable of serum-free culture; for example, the commonly used human Colorectal Adenocarcinoma cell line, Caco-2, requires the use of serum for survival and maintenance (Table 1). Yao and Asayama (2017) have published a detailed review on the history, characteristics and current issues the community is facing over animal cell culture media. The development of serum-free media has many considerations such as defining the composition and concentration of various components in the media; it has been a subject of research for many decades with limited success.

\section{The use of hydrolysate in animal cell culture}

Although animal serum is capable of supporting the growth of almost all cell lines (Zheng et al. 2006), the risks associated with its use outweigh the benefits. Furthermore, the US FDA and European Medicine Agency have tightened their rules on the use of animal-derived components in commercial protein production out of concerns for patient safety (Merten 2002; Siemensma et al. 2010). It is therefore important to investigate the essential components contain in serum that supports the growth of animal cells. Despite the availability of some animal-component-free media for selected cell lines, such media is not available for all cells, and their development often requires an enormous amount of time and money (Ballez et al. 2004). Protein digests from different types of raw materials, termed hydrolysates, have been proposed as alternatives to components in serum.

Hydrolysates are produced from enzymatic digestion and/or acid hydrolysis of micro-organism (e.g., yeast), animal proteins (off-cut, remnants) and plant proteins (e.g., soy, whey, cottonseed), or animal-derived products (e.g., milk) (Fig. 1). These raw ingredients will be pretreated with heat before digestion or hydrolysis by enzymes or chemicals (Petrova et al. 2018). Through the enzymatic/acid hydrolysis processes, a complex mixture of oligopeptides, free amino acids and carbohydrates are released from the raw material (Si and Shang 2020). Therefore, it is necessary to determine which starting materials and the optimal hydrolysis process to obtain the desired proteins and peptides. Upon hydrolysis, the product is filtered by centrifugation and ultrafiltration to remove unwanted materials (Zhang et al. 2019a, b). Finally, the resulting hydrolysate product often undergoes pasteurization to sterilize the product before spray drying and packaging (Fig. 1). Due to lot-to-lot variability in hydrolysate production, quality control $(\mathrm{QC})$ analyses are performed to determine the peptide profile within the hydrolysates. The QC analysis comprises qualitative and quantitative analysis. Under qualitative analysis,

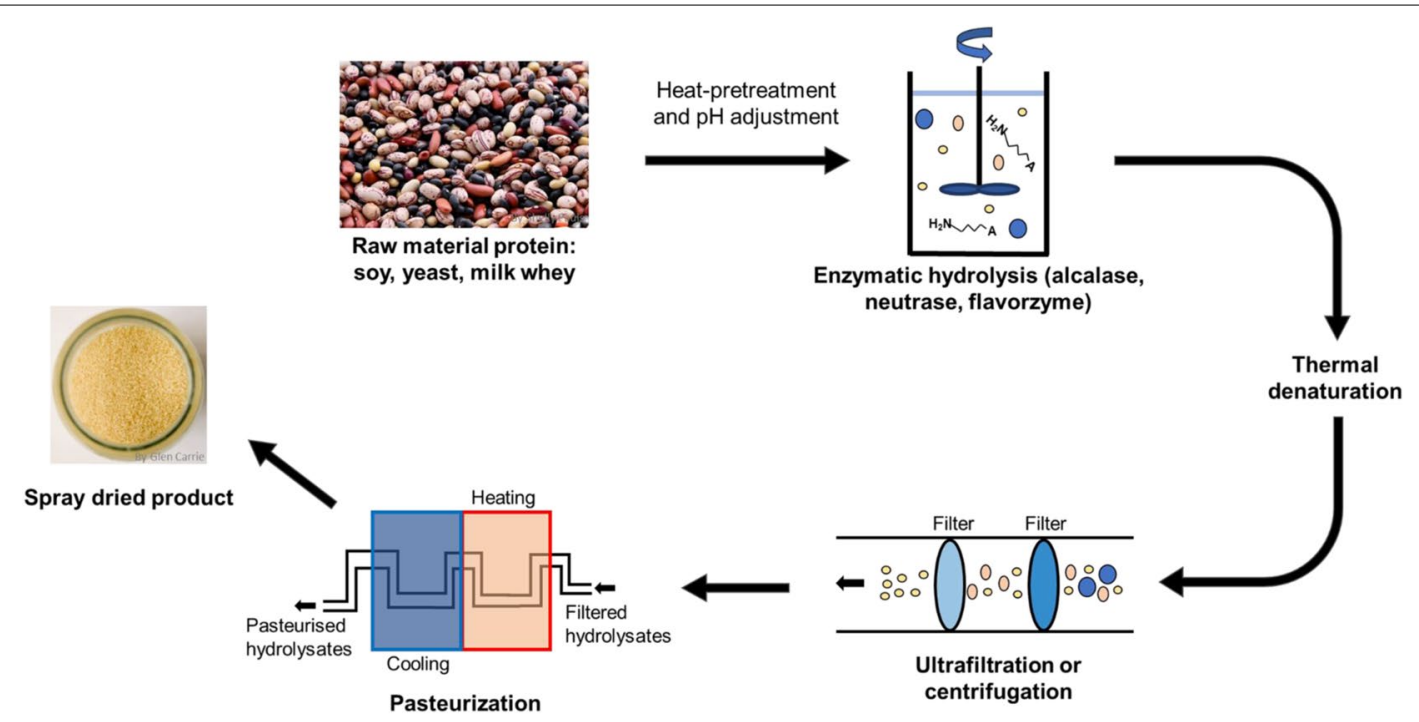

Fig. 1 Schematic of hydrolysate production. Raw materials such as soy, yeast, whey or animal proteins were pretreated with heat to break down the protein. After pH adjustment, the mixture is hydrolyzed in a chamber using enzymes, heat or subjected to extreme pH conditions. This process breaks down the protein into smaller components and releases peptides and amino acids into the solution. The degree of hydrolysis is positively correlated with the length of time in this step. Once the desired degree of hydrolysis is achieved, the mixture is again heated to denature the enzymes, followed by centrifugation and ultrafiltration to remove large insoluble particles and endotoxins. The final product is then pasteurized, spray dried and packaged. Photographs are taken from https://Unsplash.com 
monitoring of peptides at different stages of hydrolysis and protease specificity identification is performed by reverse-phase high-performance liquid chromatography (RP-HPLC). On the other hand, under quantitative analysis, cuprimetric assay complemented with total and $\alpha$-amino nitrogen determination was used to analyze amino acids and peptides since it can predict di- and tripeptide contents, hence making it more effective in differentiating homogenous hydrolysates and amino acids and poorly hydrolyzed proteins mixture (Silvestre 1997). Additionally, the degree of hydrolysis $(\mathrm{DH})$ is defined as the proportion of the number of peptide bonds being broken in a protein hydrolysate (Rutherfurd 2019). The higher the $\mathrm{DH}$, the greater the number of peptide bonds being cleaved. It can be used as a measure for digestibility, permeability and bioavailability. However, the higher the $\mathrm{DH}$ does not equate to higher bioavailability. A study was done on high (48\%), medium (27\%) and low (23\%) $\mathrm{DH}$ of whey protein and showed no correlation to the rate of amino acid plasma appearance in humans (Farup et al. 2016).

\section{Composition of hydrolysates}

The compositions of hydrolysates are highly dependent on the starting material used, the bioprocessing methods employed and the degree of hydrolysis (Zhang et al. 2019a ). Hydrolysates comprised a complex mixture of free amino acids, peptides, free acids, carbohydrates that resulted from the partial or complete hydrolysis of proteins (Table 2) (Rungruangsaphakun and Keawsompong 2018). The composition varies depending on the proteases used, hydrolysis conditions such as the duration of hydrolysis, temperature and the source of raw materials (Zhang et al. 2019a, b). During the hydrolysis process, proteins are broken down into peptides by enzymes and/or chemicals by cleaving the peptide bonds between two amino acid residues (Cheong et al. 2018). Peptides are compounds consisting of two to 20 amino acids. They are the major components in hydrolysates and have been widely investigated and reported to possess various biological activities. They are often processed from byproducts with low market value and ultimately contribute towards the reduction of waste (Petrova et al. 2018). The molecular size range of the peptides found in hydrolysates is crucial as it dictates their purposes in various applications (Pasupuleti and Braun 2010). For instance, in flaxseed and rice hydrolysates, low molecular weight peptides $(1-3 \mathrm{kDa})$ are generally known to possess better antioxidant effect in comparison to peptides larger than 3 kDa (Zhou et al. 2013; Hwang et al. 2016). The hydrolysate profile should contain mostly peptides with a molecular weight of less than 10,000 Da to be considered a non-protein (protein-free) alternative (Pasupuleti and Braun 2010). In addition to peptides, hydrolysates may contain other molecules such as vitamins, lipids and inorganic acids that could support the growth of animal cells (Table 3 ).

\section{Hydrolysates can enhance biotherapeutic protein quality and yield}

The use of hydrolysate in animal cell culture can be dated back to as early as the 1970s. It serves two main purposes in animal cell culture; first being a serum substitute for enhancing cell growth, and second as a stimulant for protein production to improve product titer and quality.

As shown in Table 3, hydrolysates have been used extensively not only to improve cell proliferation or as supplements for cells to transition into a serum-free culture, but also to improve the glycosylation profile of recombinant protein produced by $\mathrm{CHO}$. In $\mathrm{CHO}$ cells, Spearman et al. (2014) showed that soy hydrolysate promotes cell growth but did not increase protein productivity; while yeast hydrolysate reduces cell growth, but achieved a comparable level of protein productivity and glycosylation profile as an animal-based hydrolysate. This suggests that yeast hydrolysate would be a good alternative to animal-based hydrolysate if the quality of the protein produced is the most important attribute. In a more recent study, cottonseed-derived hydrolysate enhances the galactosylation of CHO-S-RTX and CHO-EG2 cells, which in turn improves the product quality (Obaidi et al. 2021). Furthermore, the glycosylation profile of the protein produced by $\mathrm{CHO}$ cells is equivalent between yeast and animal-based hydrolysate (Spearman et al. 2014). This study demonstrated that biopharmaceutical manufacturers should consider the use of yeast hydrolysates to improve protein productivity and glycosylation of the product. Apart from being a serum substitute and stimulant for titer improvement, hydrolysate products such as rice protein hydrolysate have been reported to protect $\mathrm{CHO}-320$ and human HepG2 cells against oxidative stress (Zhang et al. 2016), although the mechanisms through which these bioactive peptides enable this protection remain unknown. Different peptide fractions isolated from rapeseed hydrolysates have been used as a source of short-chain peptides with biological properties, such as immunomodulatory and protease inhibitory effects, to stimulate $\mathrm{CHO}$ cell growth and increased protein production (Farges et al. 2006).

Besides $\mathrm{CHO}$ cell culture, the use of hydrolysates like chickpea and rapeseed in replacing serum has had some successes in supporting the growth of other human cell lines, although this effect could be cell line dependent (Girón-Calle et al. 2008). For instance, a medium containing pea hydrolysate was a good serum substitute for the growth of the THP-1 cell line, but not the epithelial 
Table 2 Composition of hydrolysates

\begin{tabular}{|c|c|c|c|c|c|c|c|}
\hline \multirow{3}{*}{$\begin{array}{l}\text { References for } \\
\text { amino acids }\end{array}$} & \multicolumn{4}{|c|}{ Plant-based hydrolysate } & \multicolumn{2}{|c|}{ Animal-based hydrolysate } & \multirow{3}{*}{$\begin{array}{l}\text { Microorganism- } \\
\text { based hydrolysate } \\
\text { Yeast \%(w/w) } \\
\text { Wasserman } \\
\text { (1961), Podpora } \\
\text { et al. (2016) }\end{array}$} \\
\hline & \multirow{2}{*}{$\begin{array}{l}\text { Rice bran } \\
\text { protein } \%(w / w) \\
\begin{array}{l}\text { Amagliani et al. } \\
(2017)\end{array}\end{array}$} & \multirow{2}{*}{$\begin{array}{l}\text { Rapeseed } \\
\%(w / w)\end{array}$} & \multirow{2}{*}{$\begin{array}{l}\text { Soy protein } \\
\%(w / w)\end{array}$} & \multirow{2}{*}{$\begin{array}{l}\begin{array}{l}\text { Cotton seed } \\
\%(w / w)\end{array} \\
\begin{array}{l}\text { Cheng et al. } \\
(2020)\end{array}\end{array}$} & \multirow{2}{*}{$\begin{array}{l}\text { Atlantic salmon } \\
\%(w / w) \\
\text { Harnedy et al. } \\
\text { (2018), Nesse } \\
\text { et al. (2014) }\end{array}$} & \multirow{2}{*}{$\begin{array}{l}\begin{array}{l}\text { Chicken } \\
\text { hydrolysate } \\
\text { \%(w/w) }\end{array} \\
\text { Wu et al. (2020) }\end{array}$} & \\
\hline & & & & & & & \\
\hline Ala & 2.25 & 3.26 & 2.8 & 4.1 & 3.9 & 5.49 & 2.67 \\
\hline Arg & 2.55 & 5.23 & 4.8 & 13.2 & 2.85 & 5.78 & 1.74 \\
\hline Asn & - & 6.4 & - & - & 4.5 & - & - \\
\hline Asp & 2.91 & - & - & 9.8 & & 8.38 & 3.69 \\
\hline Cys & 0.46 & 1.13 & 0.2 & - & 0.38 & 0.61 & 0.47 \\
\hline Gln & - & 12.63 & - & - & 6.83 & - & - \\
\hline Glu & 4.39 & - & 12.4 & 22.1 & & 13.89 & 5.77 \\
\hline Gly & 1.83 & 3.82 & 2.7 & 4.3 & 4.2 & 4.03 & 1.88 \\
\hline $\mathrm{His}$ & 0.86 & 2.58 & 1.5 & 3.5 & 1.2 & 3.24 & 0.87 \\
\hline lle & 1.04 & 2.51 & 1.9 & - & 2.33 & 3.92 & 1.79 \\
\hline Leu & 1.98 & 5.11 & 5 & 3.6 & 4.13 & 7.39 & 2.61 \\
\hline Lys & 1.61 & 4.23 & 3.4 & 6.8 & 3.98 & 8.12 & 2.64 \\
\hline Met & 0.59 & NA & 0.3 & 3.5 & 1.43 & 1.87 & 0.57 \\
\hline Phe & 1.25 & 3.06 & 3.2 & 1.2 & 2.18 & 3.01 & 1.75 \\
\hline Pro & 1.29 & 4.34 & 3.3 & 7.4 & 2.55 & 2.71 & 2.42 \\
\hline Ser & 1.38 & 3.54 & 3.4 & 3.6 & 2.18 & 3.35 & 1.82 \\
\hline Thr & 1.31 & NA & 2.3 & 5.3 & 2.33 & 3.9 & 1.65 \\
\hline $\operatorname{Trp}$ & 0.44 & 0.94 & - & - & 0.6 & 0.79 & 0.49 \\
\hline Tyr & 1.06 & 2.7 & 2.2 & 3.2 & 1.88 & 2.88 & 1.38 \\
\hline Val & 1.64 & 3.51 & 2.2 & 3 & 3.08 & 4.15 & 2.19 \\
\hline $\begin{array}{l}\text { Fat/lipids (refer- } \\
\text { ence) }\end{array}$ & 2.73 & 7 & - & $\begin{array}{l}17.8 \text { (Bertrand } \\
\text { et al. 2005) }\end{array}$ & 0.5 & 8.38 & 0.2 \\
\hline $\begin{array}{l}\text { References for } \\
\text { vitamins }\end{array}$ & $\begin{array}{l}\text { Champagne et al. } \\
\text { (2004) }\end{array}$ & & $\begin{array}{l}\text { University of } \\
\text { Rochester Medi- } \\
\text { cal Center (2021) }\end{array}$ & & Nesse et al. (2014) & $\begin{array}{l}\text { Pinto e Silva et al. } \\
\text { (2008) }\end{array}$ & Wasserman (1961) \\
\hline A (retinoid) & 0 to 0.00257 & - & - & - & - & - & - \\
\hline B1 (thiamine) & 0.00857 to 0.0171 & - & $4.22 \times 10^{-8}$ & - & $1.8 \times 10^{-5}$ & 0.00007 & 0.0104 to 0.025 \\
\hline B2 (riboflavin) & $\begin{array}{l}0.00128 \text { to } \\
0.00307\end{array}$ & - & $2.53 \times 10^{-8}$ & - & $1.575 \times 10^{-5}$ & - & 0.0025 to 0.008 \\
\hline B3 (niacin) & 0.191 to 0.356 & - & $3.46 \times 10^{-8}$ & - & $3.15 \times 10^{-4}$ & - & 0.03 to 0.0627 \\
\hline B6 (pyridoxine) & 0.00643 to 0.02 & - & $2.53 \times 10^{-8}$ & - & $5.025 \times 10^{-5}$ & - & 0.0023 to 0.004 \\
\hline B9 (folic acid) & 0.000286 to 0.001 & - & - & - & $1.425 \times 10^{-5}$ & - & 0.0019 to 0.003 \\
\hline B12 (cobalamin) & 0 to 0.00257 & - & - & - & $1.2 \times 10^{-5}$ & 0.00008 & - \\
\hline Biotin & $\begin{array}{l}0.000143 \text { to } \\
0.000357\end{array}$ & - & - & - & - & - & 0.00011 \\
\hline C (ascorbic acid) & 0.0186 to 0.0929 & - & - & - & $4.275 \times 10^{-3}$ & 0.0475 & - \\
\hline Choline & 0.657 to 1 & - & - & - & - & - & - \\
\hline $\begin{array}{l}\text { E (alpha-tocoph- } \\
\text { erol) }\end{array}$ & 0 to $2.86 \times 10^{-6}$ & - & - & - & - & - & - \\
\hline Inositol & 2.86 to 5.71 & - & - & - & - & - & - \\
\hline $\begin{array}{l}\text { p-Aminobenzoic } \\
\text { acid }\end{array}$ & 0.000464 & - & - & - & - & - & 0.0015 to 0.004 \\
\hline Pantothenic acid & 0.0143 to 0.0436 & - & $1.69 \times 10^{-8}$ & - & - & - & 0.0072 to 0.0086 \\
\hline
\end{tabular}

"-" indicates no available data 


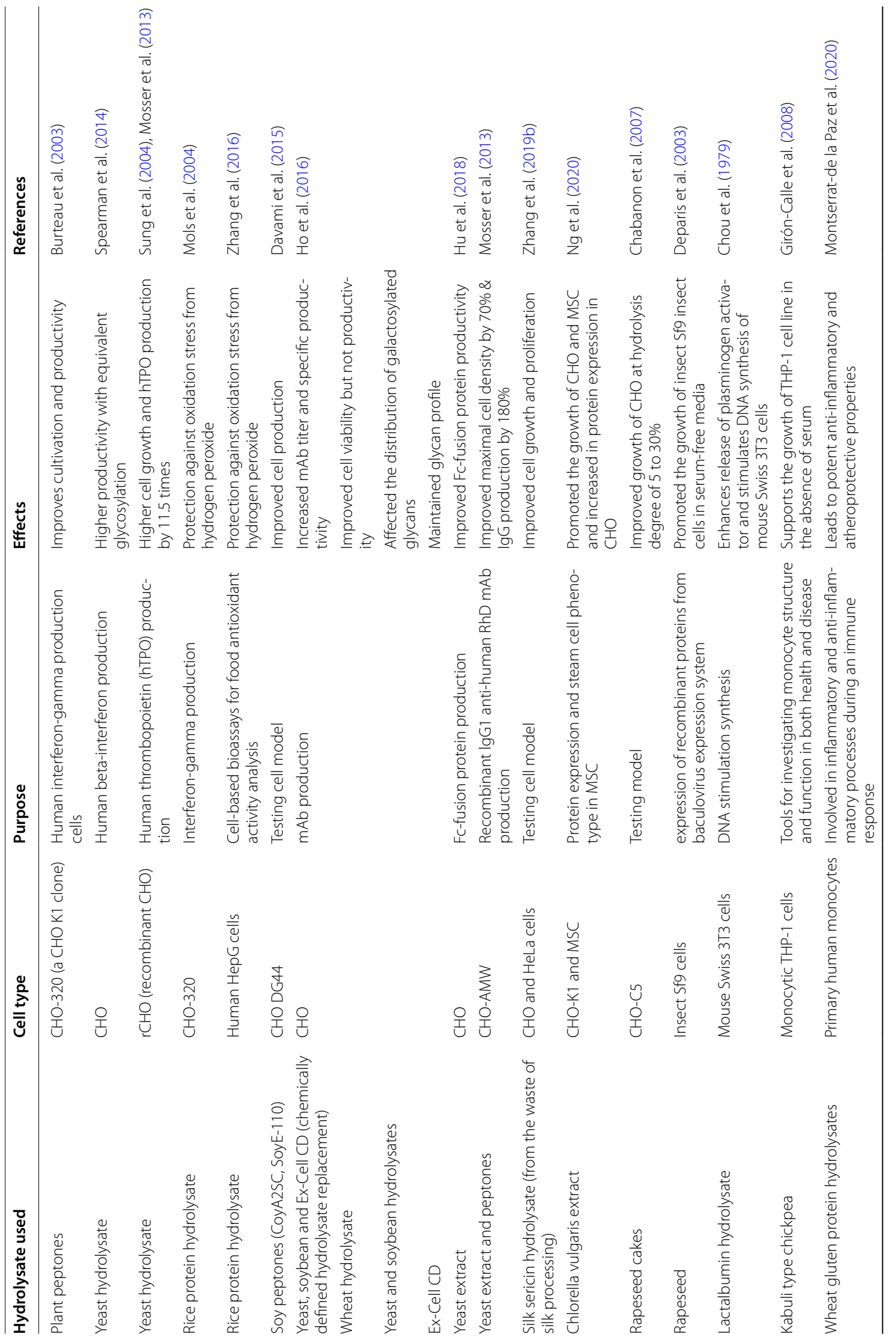




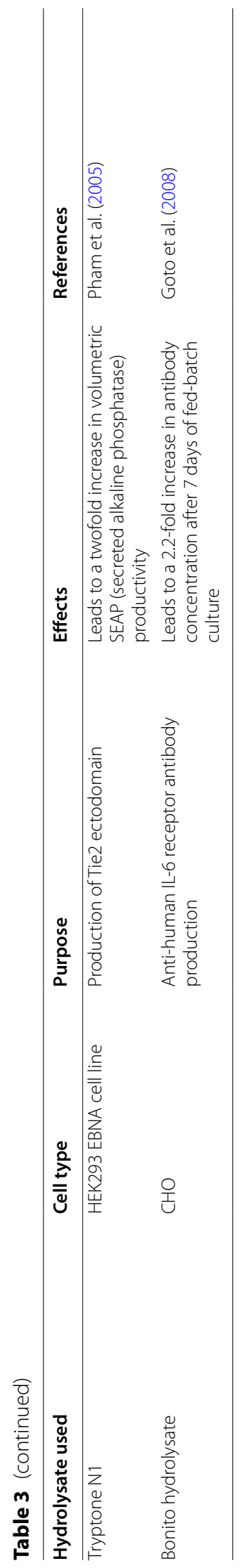


Caco-2 cell line (Girón-Calle et al. 2008) (Table 3). In HeLa cells, serum-free culture has only been recently achieved in cell media containing silk sericin hydrolysate (Zhang et al. 2019b). Once again, the underlying mechanisms governing these effects remain unknown.

Hydrolysates, as a source of free amino acids, are being used as supplements for basal medium, to sustain cell growth and to allow cell adaptation to serum-free culture media. Hydrolysates can enrich the nutritional profile of the media by increasing the stability of glutamine, and processes other beneficial bioactivities (Table 3), leading to enhanced cell viable density (Lobo-Alfonso et al. 2010; $\mathrm{Ng}$ et al. 2020). One critical drawback of using hydrolysates as media supplements is that they are undefined, leading to batch-to-batch quality issues. Indeed, it has been reported that different batches of soy hydrolysates from the same manufacturer had opposite effects on $\mathrm{CHO}$ cell-mediated mAb production (Richardson et al. 2015). Batches of soy hydrolysates that contain a high level of adenosine and arginine were negatively correlated with antibody titer in $\mathrm{CHO}$ cell culture (Richardson et al. 2015). In contrast, batches that contain a high amount of ornithine and citrulline were positively correlated with antibody titer. Citrulline and ornithine are precursors of polyamines that are very important for cell proliferation (Thomas and Thomas 2001; Richardson et al. 2015). Therefore, the effect of varying levels of pro and anti-growth factors in the different batches of hydrolysates should be thoroughly investigated.

The biopharmaceutical industry aims to formulate chemically defined culture media that contains the least number and amount of components required for cell growth and protein production. Although hydrolysates are undefined, the benefit of hydrolysate could still be realized by pre-determining the effect of hydrolysates on the cell line of interest. Furthermore, with advancements in high-resolution analytical techniques, such as chromatographic and mass spectrometric based technologies, the composition of hydrolysates can be better defined and sources of variability identified.

\section{Hydrolysates as supplements for cultured meats}

Cultured meat $(\mathrm{CM})$ is an alternative meat source that is obtained from animal cells grown in vitro rather than from animal slaughter. The purpose of having CM is mainly driven by animal welfare, environmental and sustainability concerns (Tuomisto and Teixeira de Mattos 2011). It has been discovered that animal farming contributes $18 \%$ of greenhouse gases (Steinfeld et al. 2006) and wastewater discharge from slaughterhouses contained a large amount of organic substances like fats, blood and proteins that leads to environmental pollution (Njoya et al. 2019).
Akin to biotherapeutics production, cultured meat production aims to achieve high-yielding culture producing the best quality meat. To achieve such optimal processes, exploration of different types of food-grade ingredients that can be used as growth-promoting agents for a tailor-made serum-free medium is required. O'Neill et al. (2021) have covered in a review on the considerations for the development of culture media that is cost-effective and free of animal ingredients for the production of cultured meat by replacing serum with hydrolysate. Currently, a few studies have described the use of hydrolysates as a media supplement for CM production. Tuomisto and Teixeira de Mattos (2011) reported on the use of Cyanobacteria hydrolysate to support muscle cell growth. However, the potential cytotoxicity and safety of microbe-based hydrolysate used has not been thoroughly tested and remains a safety concern. In another study, pork plasma digested with Alcalase was shown to restore bovine skeletal muscle cell function and enhanced cell growth (Andreassen et al. 2020). However, the use of animal-derived hydrolysate for CM production is counterintuitive to the purpose of being slaughter-free meat itself. It is more preferable to use plant- and yeast-based hydrolysates that have been widely used in $\mathrm{CHO}$ cell cultivation (Table 3). Hence, the usability of plant- and yeast-based hydrolysates should be thoroughly investigated in cultured meat cultivation as it provides a more economical and potentially safer option.

\section{Bioactivities of hydrolysates}

Hydrolysates consist of several components that aid in cellular survival and growth. Peptides are the major ingredient in hydrolysates mixture that possess beneficial bioactivity properties such as anti-apoptosis, antioxidant, immunomodulatory effect and antibacterial properties. Furthermore, it is valuable and of great interest in understanding the underlying biological functions of the peptides in hydrolysates as it helps to identify specific pathways taken by the cells to regulate these unique bioactivities. In addition, the information could also provide important factors for better media design.

\section{Anti-apoptotic effects}

Apoptosis is an orderly process consisting of several different biochemical reactions that leads to cellular characteristic changes and cell death. This process could be mitigated through the utilization of hydrolysates. It has been discovered that an animal-based protein hydrolysate, Primatone RL, contains factors that have antiapoptosis properties (Schlaeger 1996). In addition, several other plant-based hydrolysates have the potential to support cellular growth and survival (Franěk et al. 2000). However, the specific peptide sequences that are 
responsible for these anti-apoptotic properties are still unknown.

\section{Anti-oxidation properties}

Antioxidants are molecules that can prevent or minimize damage to cells caused by free radicals and reactive oxygen species. It has been found that hydrolysates derived from soymilk have a higher level of antioxidants as compared to raw soybean-derived hydrolysates due to the presence of anti-oxidative bioactive amino acids (tyrosine, methionine, histidine, lysine and tryptophan) through food processing (Singh et al. 2014). Other than these amino acids, hydrophobic and cysteine amino acids have antioxidant properties, with the sulfhydryl group of cysteine amino acids acting as a radical scavenger to protect cell tissue from oxidative stress (Kim et al. 2020). However, whether the anti-oxidative properties of hydrolysates can be solely attributed to these amino acids, or are in part due to the presence of even more potent antioxidants remains largely unknown.

\section{Immunomodulatory effects}

Despite the prominent rise of cell therapy, where the engineered immune cell is the product, only a handful of studies researched into the immunomodulatory effects of hydrolysates on the cell. Immunomodulatory peptides in hydrolysates have the potential to bind to the innate and adaptive immune receptors on the cell's surface, affecting proliferation, cytokines and/or antibody production (Möller et al. 2008; Kiewiet et al. 2018 ). Some hydrolysates and their derivatives were tested for their direct or indirect effects on immune cells activation or proliferation. For instance, in an ex vivo assay using primary mononuclear cells, lactoferrin was shown to reduce cytokine release (Möller et al. 2008), while stimulating the cell proliferation (Möller et al. 2008). In other cases, caseins (and digests), a milk protein, were shown to increase $\mathrm{T}$ lymphocytes proliferation (Möller et al. 2008). Despite the limited information available, it has been shown that specific amino acids such as glycine, valine, leucine, proline, glutamine and tyrosine possess immune-modulatory functions (Chalamaiah et al. 2018; Kiewiet et al. 2018 ).

\section{Antibacterial properties}

Several peptides found in hydrolysates possess antibacterial properties and have been reported as potential alternatives to overcome bacterial resistance to conventional antibiotics (Farhana et al. 2019). For instance, peptides containing basic amino acids in cottonseed hydrolysates have been reported to possess such properties (Song et al. 2020). In another study, the antimicrobial properties of chia seed hydrolysate were identified to be derived from peptides containing cationic and hydrophobic amino acids with a consensus sequence of GDVIAIR, or having the amino acid $\mathrm{K}$ as either the $\mathrm{N}$ - or $\mathrm{C}$-terminal or both (Aguilar-Toalá et al. 2020). Interestingly, it has also been found that the degree of antimicrobial activity from hydrolysates greatly depends on the enzyme used during the hydrolysis process (Tovar-Jimenez et al. 2017). Tovar-Jimenez et al. (2017) showed that hydrolyzing bovine whey protein with the aspartyl protease Eap1 enzyme, as opposed to trypsin and chymotrypsin, resulted in a hydrolysate product with markedly higher antimicrobial activity. Other antimicrobial peptides have been described in egg and camel whey hydrolysates (AlMohammadi et al. 2020; Wang et al. 2020). Thus, hydrolysates could be potentially be employed as antimicrobial agents in food and therapeutic applications.

\section{Contaminants and by-products of hydrolysate}

Since hydrolysate is a processed product, contaminants could be present in the raw material used or generated during the hydrolysis process. For example, specific yeast peptides from yeast hydrolysate and beta-glucan particularly $(1,3)-\beta$-glucan in the cell wall from yeast and plant-based hydrolysates are potentially immunogenic (Jiang et al. 2011). In addition, hydrolysates derived from microbes may contain high levels of lipopolysaccharide (LPS), an endotoxin that is difficult to completely remove from the final product (Lobo-Alfonso et al. 2010). Hydrolysates that are derived from Gram-negative bacteria like Escherichia coli would likely contain a high level of LPS contamination, which may require a more stringent postprocessing procedure for LPS removal (Xu et al. 2019).

Apart from contaminants, by-products from hydrolysates could also affect cell growth. A recent study has shown significant growth inhibition of the mAb-producing CHO-K1 GS-knockout and CHO-DG44 cells due to the accumulation of tryptophan in the culture (Alden et al. 2020). In the same study, the tryptophan-derived metabolite, 5-HIAAId (5-hydroxyindolacetaldehyde), has been shown to have a detrimental effect on cell growth (Alden et al. 2020). This observation is further supported by a separate study investigating the effects of increased levels of tryptophan by-products and riboflavin degradant (lumichrome), both of which are detrimental to cell growth (Zang et al. 2011). The author explained that high levels of the tryptophan-derived metabolite were a consequence of tryptophan degradation due to light exposure during the culture media preparation process (Zang et al. 2011). The presence of contaminants and by-products in hydrolysates is indeed a substantial drawback for most commercially available low-cost hydrolysates. Understanding how these contaminants are generated and how they can be removed from the final hydrolysate product 
would be essential to promote their use as animal serum alternatives for biomanufacturing.

\section{Working towards a chemically defined media with hydrolysates}

With the increased interest in using hydrolysates in cell culture as either a feed supplement or a component of a complete culture media formulation, the undefined nature of hydrolysates is a push back to developing a chemically defined substitute. Despite that, the nutritional profiles and bioactivities in hydrolysates are worth pursuing as serum alternatives. Two key challenges need to be addressed for hydrolysates to be more widely used in culture media formulation. Firstly, efficient methods to fractionate hydrolysate into individual components or classes of components must be developed. Liquid chromatography (LC) could be used to separate the complex mixture into multiple fractions. These fractions can then be studied to support cell growth and protein production. At this stage, the identity of the active components and in which LC fractions are unknown, but fractionating these components could eliminate toxins and other unwanted effects from the culture.

Secondly, the identification of active components in those fractions using high-resolution analytical platforms such as mass spectrometry (MS) can be performed. These platforms are specialized in the detection of low molecular weight compounds $(<3 \mathrm{kDa})$, which potentially include metabolites, oligonucleotides, or larger molecular weight compounds such as protein and peptides. In the past 5 years, there has been significant interest in the use of metabolomics platforms in food sciences to better understand how nutrition contributes to human health. The workflow of identifying the peptides in hydrolysates are: (1) peptides are separated on a column by LC; (2) their masses are analyzed on a high-resolution mass spectrometer (MS); and (3) fragmentation of each peptide is carried out to acquire the amino acid sequence (MSMS). Typically, the acquired mass spectra can then be matched against a database to deduce the identity of the peptide. However, the majority of peptides in hydrolysate comprises less than seven amino acid residues. This presents a major challenge in data analysis as database searches may not provide a unique protein sequence, but numerous matching results (hits). This challenge can be overcome by using high collision energy to dissociate peptides (also known as high collision dissociation, HCD) during fragmentation, and using high-resolution mass spectrometers such as the Orbitrap ${ }^{\text {TM }}$ (Hu et al. 2005) and time-of-flight (TOF). More importantly, $\mathrm{HCD}$ can generate immonium ions that provide a wealth of information for peptide composition. In addition to immonium ions, the neutral losses from the side chains of peptides can provide a more detailed analysis of peptide composition (Zhang et al. 2019c).

Furthermore, positively charged peptides are the most frequently studied peptides in sequencing in comparison to its counterpart, the negatively charged peptides. For many years, researchers have been investigating deprotonated peptides and described the fundamental backbone cleavages and the uniqueness in side-chain fragmentation depending on their specific side-chain structure of amino acid (Bowie et al. 2002). A study performed by Liang and colleagues investigated the side-chain neutral losses of deprotonated di- and longer chain peptides (3-6 residues) and explained how the relative abundance of certain neutral losses can estimate the specific amino acid residues (Liang et al. 2018). This information greatly assists in peptide annotation and confirmation of specific amino acid residues in peptides via either de novo sequencing or matching to a spectral library in the NIST Tandem (MS/MS) library. An example of how a dipeptide is annotated is shown in Fig. 2.

Once the peptide sequence is confirmed, the sequence can then be used to search against a database for its specific functionality, if any. There are approximately 70 peptide databases in the literature where researchers can search a particular peptide with its specific bioactivity (Minkiewicz et al. 2019). The publicly available BIOPEP-UWM database, which is fully curated, is a popular tool for bioactive peptides, especially those derived from foods (Minkiewicz et al. 2019). As of April 2021, the BIOPEP-UWM database contained 740 proteins, 4301 bioactive peptides, 135 allergenic proteins and 492 sensory peptides and amino acids. Another manually curated and publicly available peptide database is called PlantPepDB, specifically focussed on plant proteins, which currently consists of 3848 plant-derived peptides (2821 are experimentally validated) categorized according to their function (Das et al. 2020).

The identification of the active components in hydrolysates could be the first step in the development of such proteins/peptides synthetically or purified from the raw materials. This will be the first of many steps in replacing animal serum with hydrolysates in cell culture. In addition to identifying the active components in hydrolysates, developing processes that can reduce lot variability through better quality control is also important. Efforts to reduce lot-to-lot variation falls between the researcher and the manufacturer; the former could provide novel processes in the detection of components that contribute to product variation, and the latter can help to reduce variation at the point of manufacturing (Thompson and Chesher 2018). In most cases, the lot-to-lot variation is evaluated based on appropriate acceptance criteria such as biological variation outcomes and requirements. 

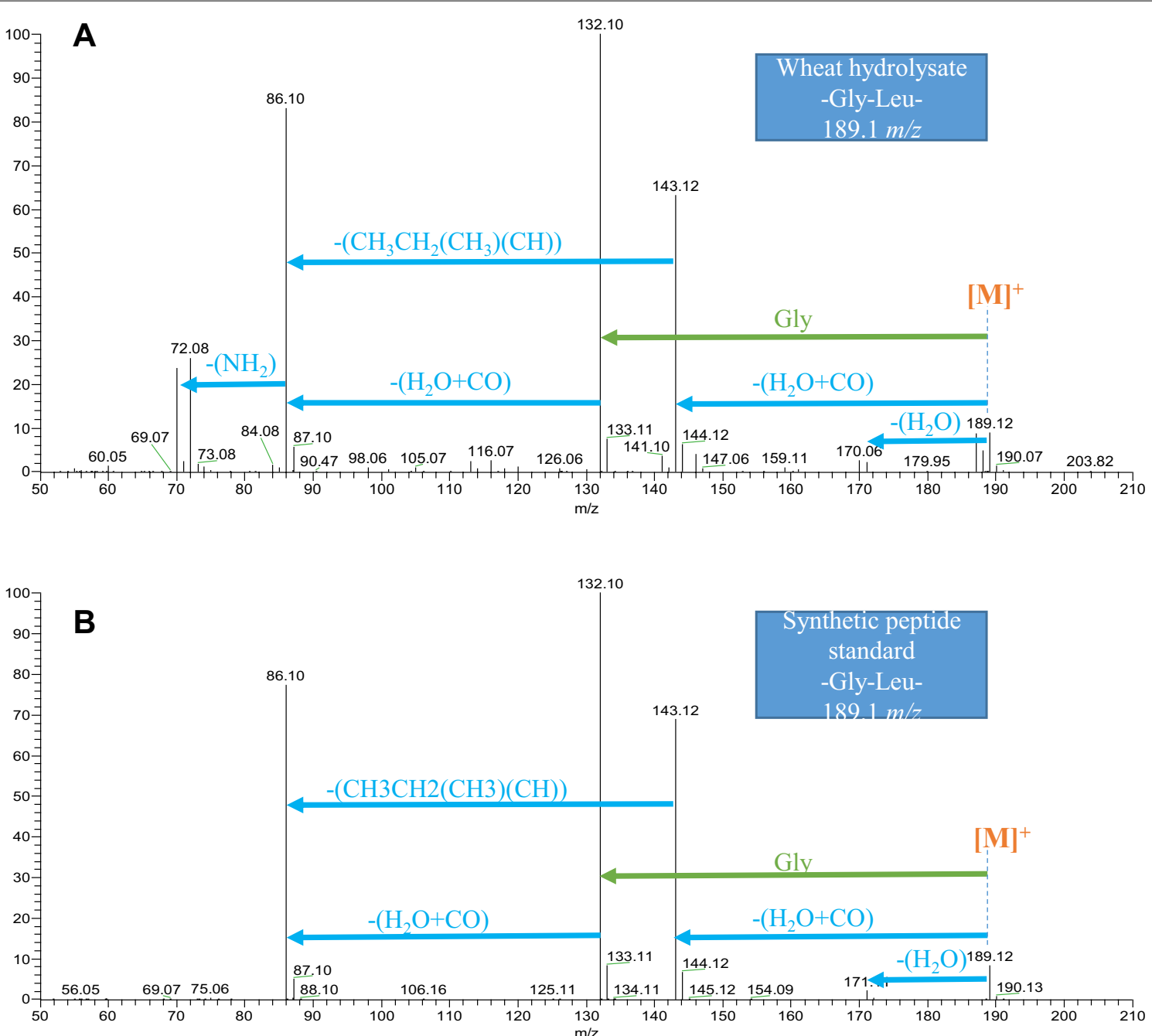

Fig. 2 A schematic of MSMS spectra of a protonated short-chain peptide, -Gly-Leu-. These MSMS spectra were acquired on an Orbitrap instrument using collision energy of NCE 10\%, showing fragmentation including neutral losses (in blue) and amino acid residue (in green). In this example, as for a dipeptide, only one peptide bond was broken, i.e., the most intense ion in the spectra, $132 \mathrm{~m} / \mathrm{z}$, loss of 57 from the molecular ion [M] $]^{+}$gives a glycine. This peptide was identified in wheat hydrolysate $(\mathbf{A})$ and as compared to a synthetic peptide $(\mathbf{B})$, both spectra are identical

Therefore, challenges faced by both researchers and manufacturers are vast not only in defining components in hydrolysates that are bioactive, but also in defining the components that contribute to lot-to-lot variation. A synergetic collaboration between the researcher and manufacturer is valuable and mutually beneficial.

\section{Conclusion}

Although animal serum contains an abundance of essential nutrients and growth factors that support the growth of many cell types, the industry is moving away from the use of animal products. Plant-based hydrolysates could be an alternative to animal serum. Studies have shown that some hydrolysates not only contain amino acids, vitamins and lipids that contribute to the basic ingredients of cell culture media, they also contain beneficial peptides and growth factors that either enhance cell proliferation or improve proteins quality, or both. Furthermore, other properties of hydrolysates such as anti-apoptotic, anti-oxidation, antibacterial, antidiabetic properties as well as immunomodulatory effects cannot be ignored. However, due to the complexity of hydrolysates, it is crucial to understand the advantages as well as challenges of using them as media supplements, such as the risk of contamination or harmful by-products that are present. Full characterization of hydrolysates, together with an in-depth analysis of the spent culture media can be used to identify its critical 
components. We propose the use of liquid chromatography together with advanced proteomics and metabolomics techniques to identify individual components or groups of components and investigate their functions in a model cell line (e.g., CHO or HEK293). This iterative process would improve our understanding of the relationship between the critical components and specific functionality, an essential step towards the formulation of serum-free chemically defined media. Hydrolysates have the potential to play a much bigger role in the everincreasing demand for cell culture media for the production of biotherapeutics products, cultured meat, as well as in the production of new modality biotherapeutics such as cell and gene therapy products.

\section{Abbreviations}

BHK: Baby hamster kidney; CAGR: Compound annual growth rate; $\mathrm{CHO}$ : Chinese hamster ovary; CM: Cultured meat; DH: Degree of hydrolysis; DHFR: Dihydrofolate reductase; FDA: Food and Drug Administration; GS: Glutamine synthetase; HCD: High-energy collision dissociation; HEK293: Human embryonic kidney cell 293; LC: Liquid chromatography; LDL: Low-density lipoproteins; LPS: Lipopolysaccharide; MS: Mass spectrometry; MSMS: Tandem MS; QC: Quality control; RP-HPLC: Reverse-phase high-performance liquid chromatography; TOF: Time-of-flight.

\section{Acknowledgements}

This review is supported by the National Research Foundation, Singapore, and the Agency for Science, Technology and Research (A*STAR) under the Singapore Food Story R\&D Programme, Grant numbers H2OH8a0003, W20W2D0009, W20W2D0008.

\section{Disclaimer}

Any opinions, findings and conclusions or recommendations expressed in this material are those of the author(s) and do not reflect the views of National Research Foundation, Singapore and the Agency for Science, Technology and Research (A*STAR)

\section{Authors' contributions}

SKN initiated the manuscript; SKN, YSH, YYH, HKL, ZFSL and HWL contributed to writing the manuscript. All authors read and approved the final manuscript.

\section{Funding}

This review is supported by the National Research Foundation, Singapore, and the Agency for Science, Technology and Research (A*STAR) under the Singapore Food Story R\&D Programme, Grant Numbers $\mathrm{H} 2 \mathrm{OH} 8 \mathrm{aO003}$, W20W2D0009, W20W2D0008.

\section{Availability of data and materials}

Data and materials are publicly available from publications as described in references.

\section{Declarations}

Ethics approval and consent to participate

Not applicable.

\section{Consent for publication}

All authors consent to the publication of the manuscript.

\section{Competing interests}

The authors declare that they have no competing interests.

Received: 2 June 2021 Accepted: 7 September 2021

Published online: 28 September 2021

\section{References}

Aguilar-Toalá JE, Deering AJ et al (2020) New insights into the antimicrobial properties of hydrolysates and peptide fractions derived from chia seed (Salvia hispanica L.). Probiotics Antimicrob Proteins 12(4):1571-1581

Alden N, Raju R et al (2020) Using metabolomics to identify cell line-independent indicators of growth inhibition for Chinese hamster ovary cell-based bioprocesses. Metabolites. https://doi.org/10.3390/metab o10050199

Al-Mohammadi A-R, Osman A et al (2020) Powerful antibacterial peptides from egg albumin hydrolysates. Antibiotics 9(12):901

Amagliani L, O'Regan J et al (2017) The composition, extraction, functionality and applications of rice proteins: a review. Trends Food Sci Technol 64:1-12

Andreassen RC, Pedersen ME et al (2020) Screening of by-products from the food industry as growth promoting agents in serum-free media for skeletal muscle cell culture. Food Funct 11:2477-2488

Ballez JS, Mols J et al (2004) Plant protein hydrolysates support CHO-320 cells proliferation and recombinant IFN- $\gamma$ production in suspension and inside microcarriers in protein-free media. Cytotechnology 44(3):103-114

Bertrand JA, Sudduth TQ et al (2005) Nutrient content of whole cottonseed. J Dairy Sci 88(4):1470-1477

Bosques CJ, Collins BE et al (2010) Chinese hamster ovary cells can produce galactose- $a-1,3$-galactose antigens on proteins. Nat Biotechnol 28(11):1153-1156

Bowie JH, Brinkworth CS et al (2002) Collision-induced fragmentations of the $(\mathrm{M}-\mathrm{H})$ - parent anions of underivatized peptides: an aid to structure determination and some unusual negative ion cleavages. Mass Spectrom Rev 21(2):87-107

Burteau CC, Verhoeye FR et al (2003) Fortification of a protein-free cell culture medium with plant peptones improves cultivation and productivity of an interferon-gamma-producing $\mathrm{CHO}$ cell line. In Vitro Cell Dev Biol 9:291-296

Carrel A, Burrows MT (1911a) An addition to the technique of the cultivation of tissues in vitro. J Exp Med 14(3):244-247

Carrel A, Burrows MT (1911b) Cultivation of tissues in vitro and its technique. J Exp Med 13(3):387-396

Chabanon G, Chevalot I et al (2007) Influence of rapeseed protein hydrolysis conditions on animal cell growth in serum-free media supplemented with hydrolysates BT. In: Smith R (ed) Cell technology for cell products. Springer, Dordrecht, pp 667-669

Chalamaiah M, Yu W et al (2018) Immunomodulatory and anticancer protein hydrolysates (peptides) from food proteins: a review. Food Chem 245:205-222

Champagne ET, Wood D et al (2004) The rice grain and its gross composition. In: Champagne ET (ed) Rice chemistry and technology. AACC, St Paul, pp 77-107

Cheng HN, He Z et al (2020) A review of cottonseed protein chemistry and non-food applications. Sustain Chem 1(3):256-274

Cheong CW, Lee YS et al (2018) Chicken feather valorization by thermal alkaline pretreatment followed by enzymatic hydrolysis for protein-rich hydrolysate production. Waste Manag 79:658-666

Cho MS, Yee H et al (2003) Versatile expression system for rapid and stable production of recombinant proteins. Biotechnol Prog 19(1):229-232

Chou IN, Prezyna C et al (1979) Isolation from lactalbumin hydrolysate of a high molecular weight mitogenic factor. J Biol Chem 254(21):10588-10591

Das D, Jaiswal M et al (2020) PlantPepDB: a manually curated plant peptide database. Sci Rep 10:2194

Davami F, Eghbalpour F et al (2015) Effects of peptone supplementation in different culture media on growth, metabolic pathway and productivity of CHO DG44 cells; a new insight into amino acid profiles. Iran Biomed J 19(4):194-205

Deparis V, Durrieu C et al (2003) Promoting effect of rapeseed proteins and peptides on Sf9 insect cell growth. Cytotechnology 42:75-85

Dumont J, Euwart D et al (2016) Human cell lines for biopharmaceutical manufacturing: history, status, and future perspectives. Crit Rev Biotechnol 36(6):1110-1122

Durocher Y, Butler M (2009) Expression systems for therapeutic glycoprotein production. Curr Opin Biotechnol 20(6):700-707 
Earle WR, Schilling EL et al (1943) Production of malignancy in vitro. IV. The mouse fibroblast cultures and changes seen in the living cells. J Nat Cancer Inst 4(2):165-212

Farges B, Tessier B et al (2006) Peptide fractions of rapeseed hydrolysate as an alternative to animal proteins in $\mathrm{CHO}$ cell culture media. Process Biochem 41:2297-2304

Farhana M, Tan HL et al (2019) Isolation of antimicrobial peptide from food protein hydrolysates: an overview. Key Eng Mater 797:168-176

Farup J, Rahbek SK et al (2016) Effect of degree of hydrolysis of whey protein on in vivo plasma amino acid appearance in humans. SpringerPlus 5:382-382

Ferreira CB, Sumner RP et al (2019) Lentiviral vector production titer is not limited in HEK293T by induced intracellular innate immunity. Mol Ther Methods Clin Dev 17:209-219

Fogh J, Wright WC et al (1977) Absence of HeLa cell contamination in 169 cell lines derived from human tumors2. JNCI 58(2):209-214

Franěk F, Hohenwarter O et al (2000) Plant protein hydrolysates: preparation of defined peptide fractions promoting growth and production in animal cells cultures. Biotechnol Prog 16:688-692

Galfrè G, Milstein C (1981) Preparation of monoclonal antibodies: strategies and procedures. Methods Enzymol 73:3-46

Gey GO (1952) Tissue culture studies of the proliferative capacity of cervical carcinoma and normal epithelium. Cancer Res 12:264-265

Ghaderi D, Zhang M et al (2012) Production platforms for biotherapeutic glycoproteins. occurrence, impact, and challenges of non-human sialylation. Biotechnol Genet Eng Rev 28:147-175

Girón-Calle J, Vioque J et al (2008) Chickpea protein hydrolysate as a substitute for serum in cell culture. Cytotechnology 57:263-272

Gorissen SHM, Crombag JJR et al (2018) Protein content and amino acid composition of commercially available plant-based protein isolates. Amino Acids 50(12):1685-1695

Goto S, Kishishita S et al. (2008) Cell culture method and utilization of the same Japan, Chugai Pharmaceutical Co Ltd

Graham FL, Smiley J et al (1977) Characteristics of a human cell line transformed by DNA from human adenovirus type 5. J Gen Virol 36(1):59-74

Harnedy PA, Parthsarathy V et al (2018) Atlantic salmon (Salmo salar) co-product-derived protein hydrolysates: a source of antidiabetic peptides. Food Res Int 106:598-606

Harrison RG, Greenman MJ et al (1907) Observations of the living developing nerve fiber. Anat Rec 1(5):116-128

Havenga MJ, Holterman L et al (2008) Serum-free transient protein production system based on adenoviral vector and PER.C6 technology: high yield and preserved bioactivity. Biotechnol Bioeng 100(2):273-283

He R, Girgih AT et al (2013) Antioxidant activities of enzymatic rapeseed protein hydrolysates and the membrane ultrafiltration fractions. J Funct Foods 5(1):219-227

University of Rochester Medical Center (2021) Nutrition facts: Soy protein isolate, potassium type, crude protein basis, 1 oz., Adult and Children's Health Encyclopedia. https://www.urmc.rochester.edu/ encyclopedia/content.aspx? contenttypeid $=76 \&$ contentid $=16423-1$. Accesed 30 May 2021

Hernandez R, Brown DT (2010) Growth and maintenance of baby hamster kidney (BHK) cells. Curr Protoc Microbiol Chapter 4:Appendix 4H

Ho SCL, Nian R et al (2016) Impact of hydrolysates on monoclonal antibody productivity, purification and quality in Chinese hamster ovary cells. J Biosci Bioeng 122:499-506

Hu Q, Noll RJ et al (2005) The Orbitrap: a new mass spectrometer. J Mass Spectrom 40(4):430-443

Hu D, Zhao L et al (2018) Physiological responses of Chinese hamster ovary cells to a productivity-enhancing yeast extract. J Biosci Bioeng 126:636-643

Hwang CF, Chen YA et al (2016) Antioxidant and antibacterial activities of peptide fractions from flaxseed protein hydrolysed by protease from Bacillus altitudinis HK02. Int J Food Sci Technol 51(3):681-689

Jayapal K, Wlaschin KF et al (2007) Recombinant protein therapeutics from $\mathrm{CHO}$ cells -20 years and counting. Chem Eng Prog 103:40-47

Jiang C, Scherfner S et al (2011) Demonstrating $\beta$-glucan and yeast peptide clearance in biopharmaceutical downstream processes. Biotechnol Prog 27:442-450
Jordan I, Vos A et al (2009) An avian cell line designed for production of highly attenuated viruses. Vaccine 27(5):748-756

Kiewiet MBG, Faas MM et al (2018a) Immunomodulatory protein hydrolysates and their application. Nutrients 10:904

Kim JY, Kim YG et al (2012) CHO cells in biotechnology for production of recombinant proteins: current state and further potential. Appl Microbiol Biotechnol 93(3):917-930

Kim J-H, Jang H-J et al (2020) In vitro antioxidant actions of sulfur-containing amino acids. Arab J Chem 13(1):1678-1684

KÖHler, G. and C. Milstein, (1975) Continuous cultures of fused cells secreting antibody of predefined specificity. Nature 256(5517):495-497

Kovesdi I, Hedley SJ (2010) Adenoviral producer cells. Viruses 2(8):1681-1703

Li F, Vijayasankaran N et al (2010) Cell culture processes for monoclonal antibody production. MAbs 2:466-479

Liang Y, Neta P et al (2018) Collision-induced dissociation of deprotonated peptides. Relative abundance of side-chain neutral losses, residuespecific product ions, and comparison with protonated peptides. J Am Soc Mass Spectrom 29(3):463-469

Lobo-Alfonso J, Price P et al (2010) Benefits and limitations of protein hydrolysates as components of serum-free media for animal cell culture applications. In: Pasupuleti VK, Demain AL (eds) Protein hydrolysates in biotechnology. Springer, Berlin, p 55

Merten OW (2002) Development of serum-free media for cell growth and production of viruses/viral vaccines-safety issues of animal products used in serum-free media. Dev Biol 111:233-257

Minkiewicz P, Iwaniak A et al (2019) BIOPEP-UWM database of bioactive peptides: current opportunities. Int J Mol Sci. https://doi.org/10.3390/ ijms20235978

Mizrahi A (1977) Primatone RL in mammalian cell culture media. Biotechnol Bioeng 19(10):1557-1561

Mordor Intelligence (2021) Biopharmaceuticals market—growth, trends, COVID-19 impact, and forecasts (2021-2026)

Möller N, Scholz-Ahrens K et al (2008) Bioactive peptides and proteins from foods: indication for health effects. Eur J Nutr 47:171-182

Mols J, Peeters-Joris C et al (2004) Origin of rice protein hydrolysates added to protein-free media alters secretion and extracellular proteolysis of recombinant interferon-gamma as well as $\mathrm{CHO}-320$ cell growth. Biotech Lett 26:1043-1046

Montserrat-de la Paz S, Rodriguez-Martin NM et al (2020) Evaluation of antiinflammatory and atheroprotective properties of wheat gluten protein hydrolysates in primary human monocytes. Foods.https://doi.org/10. 3390/foods 9070854

Mosser M, Chevalot I et al (2013) Combination of yeast hydrolysates to improve $\mathrm{CHO}$ cell growth and IgG production. Cytotechnology 65:629-641

Nesse KO, Nagalakshmi AP et al (2014) Safety evaluation of fish protein hydrolysate supplementation in malnourished children. Regul Toxicol Pharmacol 69(1):1-6

Ng JY, Chua ML et al (2020) Chlorella vulgaris extract as a serum replacement that enhances mammalian cell growth and protein expression. Front Bioeng Biotechnol 8:1068

Njoya M, Basitere M et al (2019) Analysis of the characteristics of poultry slaughterhouse wastewater (PSW) and its treatability. Water Pract Technol. https://doi.org/10.2166/wpt.2019.077

O'Flaherty R, Bergin A et al (2020) Mammalian cell culture for production of recombinant proteins: a review of the critical steps in their biomanufacturing. Biotechnol Adv 43:107552

Obaidi I, Mota LM et al (2021) The role of protein hydrolysates in prolonging viability and enhancing antibody production of $\mathrm{CHO}$ cells. Appl Microbiol Biotechnol 105(8):3115-3129

O'Neill EN, Cosenza ZA et al (2021) Considerations for the development of cost-effective cell culture media for cultivated meat production. Compr Rev Food Sci Food Saf 20:686-709

Pasupuleti VK, Braun S (2010) State of the art manufacturing of protein hydrolysates. In: Pasupuleti VK, Demain AL (eds) Protein hydrolysates in biotechnology. Springer, Dordrecht, pp 11-32

Patnaik SK, Stanley P (2006) Lectin-resistant CHO glycosylation mutants. Methods Enzymol 416:159-182 
Petrova I, Tolstorebrov I et al (2018) Production of fish protein hydrolysates step by step: technological aspects, equipment used, major energy costs and methods of their minimizing. Int Aquat Res 10(3):223-241

Pham PL, Perret S et al (2005) Transient gene expression in HEK293 cells : peptone addition posttransfection improves recombinant protein synthesis. Biotechnol Bio 90:332-344

Pinto e Silva MEM, Paton I et al (2008) Mineral and vitamin content of beef, chicken, and turkey hydrolysates - mineral and vitamin content of protein hydrolysates. Quim Nova. https://doi.org/10.1590/50100-4042200800 0100008

Podpora B, Swiderski F et al (2016) Spent brewer's yeast extracts as a new component of functional food. Czech J Food Sci 34:554-563

Ponten J, Saksela E (1967) Two established in vitro cell lines from human mesenchymal tumours. Int J Cancer 2(5):434-447

Rasheed S, Nelson-Rees WA et al (1974) Characterization of a newly derived human sarcoma cell line (HT-1080). Cancer 33(4):1027-1033

Richardson J, Shah B et al (2015a) Metabolomics analysis of soy hydrolysates for the identification of productivity markers of mammalian cells for manufacturing therapeutic proteins. Biotechnol Prog 31:522-531

Rodríguez-Hernandez C, Torres-García S et al (2014) Cell culture: history, development and prospects. Int J Curr Res Acad Rev 2:188-200

Rungruangsaphakun J, Keawsompong S (2018) Optimization of hydrolysis conditions for the mannooligosaccharides copra meal hydrolysate production. 3 Biotech. https://doi.org/10.1007/s13205-018-1178-2

Rutherfurd SM (2019) Methodology for determining degree of hydrolysis of proteins in hydrolysates: a review. J AOAC Int 93(5):1515-1522

Schlaeger E-J (1996) The protein hydrolysate, Primatone RL, is a cost-effective multiple growth promoter of mammalian cell culture in serum-containing and serum-free media and displays anti-apoptosis properties. J Immunol Methods 194:191-199

Schneider U, Schwenk H-U et al (1977) Characterization of EBV-genome negative "null" and "T"cell lines derived from children with acute lymphoblastic leukemia and leukemic transformed non-Hodgkin lymphoma. Int J Cancer 19(5):621-626

Sha S, Agarabi C et al (2016) N-glycosylation design and control of therapeutic monoclonal antibodies. Trends Biotechnol 34(10):835-846

Si D, Shang T et al (2020) Production and characterization of functional wheat bran hydrolysate rich in reducing sugars, xylooligosaccharides and phenolic acids. Biotechnol Rep 27:e00511

Siemensma A, Babcock J et al (2010) Towards an understanding of how protein hydrolysates stimulate more efficient biosynthesis in cultured cells. In: Pasupuleti VK, Demain AL (eds) Protein hydrolysates in biotechnology. Springer, Berlin, p 33

Silvestre MPC (1997) Review of methods for the analysis of protein hydrolysates. Food Chem 60(2):263-271

Singh BP, Vij S et al (2014) Functional significance of bioactive peptides derived from soybean. Peptides 54:171-179

Song W, Kong X et al (2020) Antioxidant and antibacterial activity and in vitro digestion stability of cottonseed protein hydrolysates. LWT 118:108724

Soule HD, Vazguez J et al (1973) A human cell line from a pleural effusion derived from a breast carcinoma. J Natl Cancer Inst 51(5):1409-1416

Spearman M, Lodewyks C et al (2014) The bioactivity and fractionation of peptide hydrolysates in cultures of CHO cells. Biotechnol Prog 30(3):584-593

Steinfeld H, Gerber P et al (2006) Livestock's long shadow. Food and Agriculture Organization of the United Nations, Rome

Sung YH, Lim SW et al (2004) Yeast hydrolysate as a low-cost additive to serumfree medium for the production of human thrombopoietin in suspension cultures of Chinese hamster ovary cells. Appl Microbiol Biotechnol 63:527-536

The Business Research Company (2021). Monoclonal antibodies (MAbS) global market report 2021: COVID-19 impact and recovery to 2030. T. B. R. company. Global. p 200

Thomas T, Thomas TJ (2001) Polyamines in cell growth and cell death: molecular mechanisms and therapeutic applications. Cell Mol Life Sci 58:244-258

Thompson S, Chesher D (2018) Lot-to-lot variation. Clin Biochem Rev 39(2):51-60

Tjio JH, Puck TT (1958) Genetics of somatic mammalian cells. II. Chromosomal constitution of cells in tissue culture. J Exp Med 108(2):259-268

Todaro GJ, Green H (1963) Quantitative studies of the growth of mouse embryo cells in culture and their development into established lines. J Cell Biol 17(2):299-313
Tovar-Jimenez X, Muro C et al (2017) Hydrolysate antimicrobial activity released from bovine whey protein concentration by the appartyl protease Eap1 of Sporisoriun reilianum. Rev Mex Ing Quim 16:11-18

Tsuchiya S, Yamabe M et al (1980) Establishment and characterization of a human acute monocytic leukemia cell line (THP-1). Int J Cancer 26(2):171-176

Tuomisto HL, Teixeira de Mattos MJ (2011) Environmental impacts of cultured meat production. Environ Sci Technol 45:6117-6123

Vink T, Oudshoorn-Dickmann M et al (2014) A simple, robust and highly efficient transient expression system for producing antibodies. Methods 65(1):5-10

Wang R, Han Z et al (2020) Antibacterial activity of trypsin-hydrolyzed camel and cow whey and their fractions. Animals. https://doi.org/10.3390/ani10 020337

Wasserman AE (1961) Amino acid and vitamin composition of saccharomyces fragilis grown in whey. J Dairy Sci 44(3):379-386

Wölfel J, Essers R et al (2011) CAP-T cell expression system: a novel rapid and versatile human cell expression system for fast and high yield transient protein expression. BMC Proc 8(Suppl 8):133

Wu P-T, Lau Y-Q et al (2020) Ability of chicken protein hydrolysate to lower serum cholesterol through its bile acid binding activity. CyTA 18(1):493-499

Wurm FM (2004) Production of recombinant protein therapeutics in cultivated mammalian cells. Nat Biotechnol 22(11):1393-1398

Wurm FM, Wurm MJ (2017) Cloning of CHO cells, productivity and genetic stability-a discussion. Processes 5(2):20

Xu X, Nagarajan H et al (2011) The genomic sequence of the Chinese hamster ovary (CHO)-K1 cell line. Nat Biotechnol 29(8):735-741

Xu Q, Bai F et al (2019) Utilization of acid hydrolysate of recovered bacterial cell as a novel organic nitrogen source for L-tryptophan fermentation. Bioengineered 10(1):23-32

Xu J, Xu X et al (2020) Biomanufacturing evolution from conventional to intensified processes for productivity improvement: a case study. MAbs 12:1770669

Yamaguchi K, Itoh K et al (2003) Engineered long terminal repeats of retroviral vectors enhance transgene expression in hepatocytes in vitro and in vivo. Mol Ther 8(5):796-803

Yao T, Asayama Y (2017) Animal-cell culture media: history, characteristics, and current issues. Reprod Med Biol 16(2):99-117

Yasumura Y, Kawakita Y (1963) Studies on SV40 in tissue culture-preliminary step for cancer research in vitro. Nihon Rinsho 21:1201-1215

Zang L, Frenkel R et al (2011) Metabolomics profiling of cell culture media leading to the identification of riboflavin photosensitized degradation of tryptophan causing slow growth in cell culture. Anal Chem 83:5422-5430

Zhang XX, Li W, Wang R, Luo XH, Li Y, Chen ZX (2016) Protective effects of rice dreg protein hydrolysates against hydrogen 2 peroxide-induced oxidative stress in HepG-2 cells. Food Funct. https://doi.org/10.1039/c5fo01183c

Zhang Y, Tu D et al (2019a) Fish scale valorization by hydrothermal pretreatment followed by enzymatic hydrolysis for gelatin hydrolysate production. Molecules. https://doi.org/10.3390/molecules24162998

Zhang M, Cao T-T et al (2019b) Silk sericin hydrolysate is a potential candidate as a serum-substitute in the culture of Chinese hamster ovary and henrietta lacks cells. J Insect Sci 19:10

Zhang P, Chan W et al (2019c) Revisiting fragmentation reactions of protonated a-amino acids by high-resolution electrospray ionization tandem mass spectrometry with collision-induced dissociation. Sci Rep 9(1):6453

Zheng X, Baker H et al (2006) Proteomic analysis for the assessment of different lots of fetal bovine serum as a raw material for cell culture. Part IV. Application of proteomics to the manufacture of biological drugs. Biotechnol Prog 22(5):1294-1300

Zhou K, Canning C et al (2013) Effects of rice protein hydrolysates prepared by microbial proteases and ultrafiltration on free radicals and meat lipid oxidation. LWT Food Sci Technol 50(1):331-335

\section{Publisher's Note}

Springer Nature remains neutral with regard to jurisdictional claims in published maps and institutional affiliations. 